\title{
A review of the forms, rationale, and challenges of supplier development in public procurement: lessons for public buyers in Tanzania
}

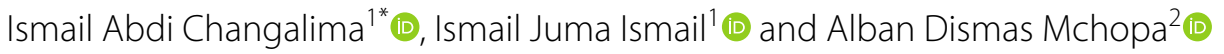

\begin{abstract}
This article synthesizes current insights into supplier management practices that professional buyers can apply in the public procurement context. Specifically, it discusses the practices, rationale, and challenges associated with implementing supplier development as an important activity within supplier management practices. Drawing from the literature, the main arguments are on the applicability of indirect supplier development practices in the public procurement context. Therefore, it is concluded that public buyers can consider applying these practices in public organizations. However, caution should be exercised regarding the legal and regulatory structure that governs the country's public procurement system. It further recommends empirical studies to be done on supplier development practices for local suppliers in specific public procurement projects.
\end{abstract}

Keywords: Supplier development practices, Public procurement, Public buyers, Procurement professionals, Public organizations

\section{Introduction}

Historically, supplier development elements were first introduced in the manufacturing sector. For example, in the late 1930s, the purchasing rules established by Toyota Motor Corporation entailed treating suppliers as part of the cooperation [70]. Literally, it dates back to the dawn of management and business [42]. It merely entails working closely with suppliers, sharing information, and some collaboration initiatives. But, over the last decades, supplier development has been an area of interest for several practitioners and researchers $[20,83]$. This is because most organizations currently treat suppliers as part of their operations. Traditionally, decisions related to supplier development were solely the responsibility of the

\footnotetext{
*Correspondence: changalima@gmail.com

${ }^{1}$ Department of Business Administration and Management, The

University of Dodoma, P.O. Box 1208, Dodoma, Tanzania

Full list of author information is available at the end of the article
}

purchasing function, as purchasing professionals were well equipped with the know-how for developing suppliers. [28]. However, at the moment, these professionals are involved in strategic functions more often [15, 27]. Therefore, decisions related to supplier development are made considering the organization's top management staff $[26,46]$.

Several studies based on empirical and theoretical approaches have examined the concept of supplier development, resulting in diversified literature relating to the management of suppliers [32, 38, 58]. However, studies on the applicability of supplier development practices in the public procurement context remain unclear and limited across research findings. Therefore, this article focuses on synthesizing insights into the supplier development practices that procurement professionals within the public sector may apply when executing their public procurement functions. Thus, this article contributes significantly to supplier development literature in the public 
procurement context. Also, it provides insights into the applicability of supplier development practices for public buyers. Moreover, this article points out areas for further research, such as proposing a legal framework for the applicability of supplier management on public procurement to advance our understanding of the topic. This is because, in most cases, regulatory compliance has been found as the main hindrance to the application of direct supplier development.

Generally, the research program surrounding supplier development from a procurement perspective represents diverse themes, with most studies conducted in manufacturing and service industries. For instance, there is a strand of literature that explores the meaning and types [16], elements [39], factors and elements [38, 73], conditions for supplier development activities [89], and supplier development with performance in various dimensions [11, 43, 53, 72, 88, 92], in buyer-supplier relationships [80], and outsourcing [43]. Recently, the study conducted by [35] focused on supplier development for small to medium-sized micro-enterprises through incubation programs from which support services are provided and the formation of business partnership structures for these enterprises. Still, others emphasized the importance of supplier management practices and sustainability [44]. Therefore, it is clear that reviewed literature focuses on supplier development mainly in different contexts, including manufacturing firms, private services firms.

Despite previous researchers' efforts on the topic, very little publication space has been devoted to the subject of synthesizing what is known about the applicability of supplier development in the public sector, particularly in procurement activities that are regarded as vital in various dimensions (social and economic). Moreover, literature shows that knowledge of supplier development practices is detached as presented in various research findings. This limits the widespread literature by relying on the single side of manufacturing firms that are merely private and little on the public procurement context. So, the purpose is to synthesize available literature and present supplier development practices applicable in a public procurement context. This is relevant because public buyers who are regarded as procurement professionals in their respective public organizations have the chance of benefiting from the applicability of supplier development practices while also pointing out the gaps in the current literature on supplier development practices.

Public procurement generally is the process by which public organizations acquire goods, services, and works from external suppliers, services providers, or contractors [84]. The interest in studying public procurement functions is that the amount of money directed toward the public procurement function is enormous. For instance, in 2015, it was reported that public procurement represents the largest share, accounting for almost onethird of public procurement spending in Organisation for Economic Co-operation and Development (OECD) countries, amounting to $29.8 \%$ [60] and $29.1 \%$ of general government expenditures in 2017 [61]. Furthermore, the public procurement function accounts for about $50 \%$ and more in developing countries [36]. Therefore, given the magnitude of public procurement spending, it is critical to synthesize supplier development activities in this context, where suppliers are heavily involved.

The rest of this article is divided into three parts. The following part provides the methodology adopted in this article. The second part provides the results and discussion that clarifies the meaning, forms, rationale, challenges of supplier development, and challenges of applying supplier development in public procurement. Finally, the last part provides conclusions and points out implications for further studies.

\section{Methods}

This section provides the methodological insights that were applied during the search and synthesis of relevant available literature. Our current study adapted a methodology used by [62] to obtain the relevant literature. In their work, they employed four primary methods. These adapted methods are clearly explained as follows:

Search strategy: most of the studies that center on literature review focus on identifying the first keywords that will be used during the literature search $[2,23,62,65$, $76,86]$. Therefore, Google Scholar was the most queried platform used during the literature search with search terms such as "supplier development," "supplier development practices," "and supplier development activities," "supplier development in public procurement" with no time limit. From this search strategy, key scientific contributions were obtained for reviews. The study included Google Scholar as most reputable electronic databases are linked with this platform. Therefore, pertinent literature was obtained from electronic databases like Springer, Elsevier, Sage Publishing, Wiley, Emerald, and Taylor and Francis. Like other previous studies [23, 27], the current study also included literature that centers on the prior mentioned keywords of this study were considered for further analysis.

Study eligibility criteria: although [62] included only articles with all the searched items, the current study included all articles which presented themes related to the searched terms and at least one of them. For a broad search of the literature, it is crucial to include both keywords and free text words that are relevant to the current study [23]. This was done to guarantee that our study 
contained a sufficient number of relevant publications. However, caution was exercised, as [62] pointed out that ensuring that all search keywords are included in the article's abstract or introduction is likely to omit certain articles that may have been relevant.

Report eligibility criteria: our review included both empirical and theoretical articles that were only published in English. Only articles presented in the English language were considered because researchers are familiar with the language, and the majority of published articles from the searched databases are in English. Also, the focus was more on the journal articles since they are peer-reviewed and rigorous. Therefore, unpublished literature was not mostly considered in this study as it was not easy to ascertain how meticulous the blind review process was.

Analytical strategy: in a similar context as [62], the data analysis in our study involved a thematic analysis whereby patterns and themes of reviewed articles were identified. As opined by [59], through thematic analysis, researchers can identify themes and patterns that exist in the literature. In this aspect, some of the themes created by researchers in this current study are included in the next section, "results and discussion." This was done so as to keep the focus of the study on the main ideas that are pointing out various meanings, forms, rationale, and challenges related to supplier development practices available in the surveyed literature. These themes are discussed in relation to the public procurement context, as the same in a content analysis obtained themes in the literature enables researchers to draw some interpretation of the results [10].

\section{Results and discussion}

\section{Conceptual meanings of supplier development practices}

In this section, various conceptual meanings, forms, rationale, and challenges of supplier development are presented as extracted from the reviewed literature. Also, the same are discussed in relation to the context of public procurement so as to capture the aspects under which public buyers can apply supplier development practices.

Table 1 shows various definitions of the concept of supplier development as presented in surveyed literature. It should be noted that the given definitions are not exhaustive, although they adequately capture the basic concepts underlying the concept of supplier development. Most given definitions conceptualize the concept of supplier development in the context of improving and enhancing the capabilities of suppliers. This activity is conducted by the buying organization so that its suppliers can meet the needs and requirements of the given buying organization.

\section{Forms of supplier development practices}

Generally, most previous surveyed literature identifies supplier development practices into two main categories: indirect and direct supplier development practices $[1,78$, 88]. For instance, indirect supplier development activities may consist of setting suppliers' targets, incentives and penalties, communication, and certifications $[1,87,88$, $93,96]$. On the other hand, practices like on-on-site consulting, training, capital equipment, providing a swap of equipment or funds, and monetary rewards are just some of the methods that direct supplier development facilitates suppliers to get better results [55].

On the other hand, [7] identified supplier development practices in the form of investments in terms of tangible and intangible practices. However, the same practices that were regarded as direct supplier development practices are considered both tangible and intangible supplier development investment practices. These may include technological and human investment, sending employees from the buyers to the suppliers, capital resources, and rewarding suppliers for their better performance [7, 55, 87, 88]. Through intangible knowledge investment,

Table 1 Conceptual meaning of supplier development

\begin{tabular}{ll}
\hline Author(s) & Conceptual meaning of supplier development \\
\hline [39] & $\begin{array}{l}\text { Supplier development refers to any "effort done by the buying organization" with its suppliers to "enhance the performance of those } \\
\text { engaged suppliers and/or their capabilities" to meet the supply needs of the buying organization }\end{array}$ \\
& $\begin{array}{l}\text { Supplier development is defined as "any activity that a buying organization" conducts to "improve the performance and capabilities of its } \\
\text { suppliers" to meet the supply needs of the buying organization }\end{array}$ \\
& $\begin{array}{l}\text { Supplier development can be defined as any activities that are conducted by a buying organization focusing on "identifying, measuring, } \\
\text { and improving the performance of the supplier" and facilitating "the continuous improvement of the overall value of goods and services" } \\
\text { provided by the supplier to the buying organization }\end{array}$ \\
& $\begin{array}{l}\text { Supplier development can be defined as "the cooperation" between a buying firm and suppliers, "focusing on continuously improving the } \\
\text { performance of suppliers" }\end{array}$ \\
[90] Supplier development refers to "the long-term cooperative initiative" among a buying organization and its suppliers to "upgrade the tech- \\
nical, quality, delivery, and cost capabilities of suppliers" to facilitate continuous improvements
\end{tabular}


potential suppliers are provided with technical expertise and trained to control costs, design product development, and solve problems jointly on arising issues [7]. Also, direct supplier development practices may include enhancing technical and financial assistance to suppliers, investing in suppliers' operations, and providing training and educating suppliers [94]. It has been observed that suppliers may be characterized by opportunistic behavior when engaged in direct supplier development, which presents problems for the overall purpose of developing potential suppliers [87].

In the context of public procurement, most indirect supplier development practices are more likely to be performed [50]. Even though buyers may be less committed to facilitating resources to suppliers when engaged in indirect supplier development practices [96], this may enable public buyers to engage in supplier development practices in other aspects other than investing in supplying companies' resources, which seems to be the case. Some indirect supplier development practices, such as supplier visiting, supplier performance measurements, feedback, effective communication, supplier auditing, recognition, and supplier assessments [38], are applicable in public procurement contexts. However, in most cases, indirect supplier development practices rely on ensuring that suppliers are monitored in terms of their operational performance. On the other hand, most direct supplier development activities are considered to be the case for promoting the capabilities of engaged suppliers [88].

Therefore, most direct supplier development activities are unlikely to be performed in public procurement functions for various reasons. The reasons may include the legal framework structure, the competitive focus of most public procurement undertakings, and the nature of the transactional focus of procurement functions in public organizations. However, the literature shows some success stories related to implementing supplier development practices. For instance, in Chile, [4] reported that the Chilean supplier development program which the Chilean government conducted enabled buyers to help suppliers in different functions across the supply chain. This was a successful initiative that was later adopted by other courtiers, including Uruguay, Mexico, and Colombia [1]. In addition, the program helped suppliers in various areas, including quality control, performance metrics identification, and initiatives on strategic sourcing.

Similarly, the benefits can be realized for suppliers in the public procurement context through structuring and shaping the procurement legal framework in favor of supplier development practices. Using knowledge from other countries such as the UK, Chile, and Mexico [4, $5,24]$, which have successfully implemented supplier development programs. These learned lessons present an opportunity for developing countries to reform their public procurement legislative frameworks in order to improve formal supplier development procedures in the future. For example, like most countries, public procurement activities in Tanzania are governed by the regulatory framework [15, 48]. This calls for compliance with procurement law and regulations when deciding to develop potential suppliers. Empirically, [8] opined that apart from the top management support in organizations, government regulations are needed to support supplier development programs externally. Therefore, government regulations related to supplier development programs may also enable public buyers to utilize the benefits of developing suppliers in public procurement fully.

\section{The rationale of supplier development}

The original motive of enhancing supplier development practices is necessary for ensuring that suppliers can perform as to the buyers' expectations. In manufacturing organizations, supplier development practices enable both suppliers and manufacturers to enhance competitive advantages [19]. Also, the literature shows that through supplier development practices, suppliers can increase their performance to enable manufacturing firms to meet their needs, improve product reliability, design, and manufacturing of new products, reduce production costs and finally meet the needs of their ultimate customers $[6,41,83]$.

Buying organizations can enhance relationships with significant suppliers by applying supplier development practices $[33,80]$. Even though public organizations are not likely to enhance relationships with suppliers, there is room for public professional buyers to manage relationships with their suppliers. Therefore, the application of supplier development practices in public procurement may provide room for professional buyers in public organizations to enhance supplier-buyer relationships and benefit from these established relationships, as shown in the vast literature [31, 57, 63].

Additionally, a stream of literature shows that green procurement practices are necessary for public organizations [12, 82]. It should be noted that through social [56], economic, and environmental aspects [22] in public procurement activities, organizations can achieve sustainability. As a result, public buyers are urged to ensure that procurement practices within their organizations are geared toward acquiring goods and services that take into account the three main aspects of sustainability: social, environmental, and economic aspects of public procurement [22]. Furthermore, studies show that aspects of environmentally friendly procurement activities are well enhanced through supplier development practices $[1,12$, 
$69,85]$. Also, social and societal issues could be improved through supplier development practices [93, 94].

Supplier development practices are associated with the enhancement of the performance of suppliers in financial and operational aspects $[5,18,53]$, the satisfaction of suppliers [25] on the other side, and that of the buyer on another side through improving purchasing performance [74]. In addition, it should be noted that through supplier development practices, procured products can be easily made available to the premises of the buyers through better delivery schedules and supply flexibility [30,92] and enhancement of internal quality [71]. Therefore, this can be a wake-up call for public buyers in the public procurement context. By embracing supplier development practices in public organizations, the purchasing performance can be enhanced to meet their respective organizations' expected needs and requirements.

Moreover, the business environment calls for innovation, which is considered the most critical strategic priority obtained from the organization's supply base [47]. The literature shows that supplier development programs provide room for enhancing innovations in the public sector [52] and enhancing supplier innovativeness [64], which are essential in public procurement functions. Inputs can also be obtained by buying organizations during the development of new products [77]. Most public organizations engaging in procurement activities may receive the necessary information for new procurement items in terms of specifications suggested by potential engaged suppliers. Procurement professionals in their respective organizations are responsible for linking suppliers and organizational functions [3]. Similarly, [39] opined that the procurement department could help enhance procurement functions in their respective organizations through supplier development practices.

Buyers initiate supplier development programs, and the literature shows that knowledge transfers from buyers to suppliers can improve supplier performance when implemented in supplier development programs [53]. A stream of empirical studies shows that firms can achieve competitive advantage in vertical relationships when there is effective knowledge transfer between them [9, 45]. In the context of public procurement, there are various ways in which professional buyers can share knowledge with potential suppliers. Through effective communication, buyers are able to share important information with suppliers prior to contractual arrangements [29]. Even though supplier development may occur through informal buyer-supplier interactions [51], public buyers can ensure that suppliers are provided with information related to tenders and training opportunities that enhance their capabilities. For example, in developing countries like Tanzania, public procurement practitioners and relevant organs, including the country procurement professional board named Procurement and Supplies Professionals and Technicians Board (PSPTB) and Public Procurement Regulatory Authority (PPRA), conduct training and workshops for both professional buyers and suppliers on various matters related to public procurement activities.

When it comes to supplier development activities, information dissemination is crucial [79]. The information shared can also enhance the shaping and have detailed specifications for the requirements of the buyer during the need analysis phase. For example, information related to the availability of tender opportunities that are disclosed through general procurement notices enables respective suppliers to prepare themselves for bidding. This may enable potential suppliers to explore new business opportunities and advise them on the tender opportunities [50]. However, professional buyers in the public sector can guarantee that the information provided in connection with bids and other public procurement is in line with the legislative framework. The literature shows that the development of suppliers in the public sector is lagging behind due to the fact that regulatory compliance constraints the way suppliers and public buyers interact [50]. In this regard, the power that buyers have in relation to the development of potential suppliers in public procurement should be well guided by the existing procurement law and regulations.

The goal of developing suppliers is to ensure that there is an improvement in the current pool of suppliers to meet the needs of the buying organizations. Public buyers in Tanzania can ensure that engaged suppliers are provided with the necessary information related to the availability of tenders and opportunities and communication throughout the period of procurement for clarifications and improvements. Furthermore, greater emphasis should be placed on attending training sessions provided by PSPTB, PPRA, and other stakeholders to ensure that suppliers are familiar with the requirements for capturing public procurement opportunities. Individual professional buyers can enhance supplier flexibility through developing suppliers by sharing necessary information on the current orders and future demands. Information sharing improves the innovative capabilities of potential suppliers to cope with the demands of the buyers so as to satisfy buyers' needs and, at the same time, helps develop themselves. For example, suppose buyer $X$ from public procuring entity $Y$ wants to develop supplier $Z$. He should provide the necessary information regarding the requirements of the ordered goods and services as per the procurement contracts. As a result, it is more likely for supplier $Z$ to improve the delivery schedules, which in turn results in meeting the needs of buyer $X$ and public 
procuring entity $Y$. However, the same should be done by considering the requirements of the procurement contract and existing laws and regulations. This may enhance supplier development without affecting the level of regulatory compliance that may affect the overall objective of public procurement.

\section{Challenges of supplier development}

Some challenges have been reported by a strand of literature on the implementation of supplier development practices which may affect the desirability of success stories for proper implementation of supplier development programs and initiatives in the context of public procurement. For example, studies conducted by [54] and [14], as cited by [1], show that some barriers hinder the success of supplier development. These barriers are categorized into two categories which include barriers originating on the buyer and supplier side, on the other hand. Some buyer-based barriers include the nonexistence of strategic focus, purchase or load volumes that are not balanced, lack of cross-functional teams, cost-oriented, and organizational culture. On the supplier side, barriers include inadequate strategic planning, problems in investing, hesitation in sharing information, trust and dependence issues, nonstructural and uniform information $[1,14,54]$. All these issues may affect the objectives and outcomes of supplier development practices in the buyer-supplier relationships.

Also, from time to time, the development of the supplier demands that the buyer and the supplier companies devote their finances, their capital, and their personnel resources toward the overall performance. Thus, this approach becomes a challenging one for both parties. Executives of buyers must be persuaded that investing in a supplier is a worthwhile risk [17]. This poses a challenge to supplier development practices, as parties will not always be willing to invest in the relationships unless they are sure that they will benefit. However, this is not the case for direct supplier development practices that may require an investment of financial and other resources to ensure that the suppliers' capabilities are enhanced to meet the buyer's expectations [53, 88]. In addition, sometimes buying organizations are reluctant to develop suppliers [37, 83]. This may be due to perceived challenges associated with the process, and costs involved in the supplier development practices may not justify the benefits to be achieved by either of the parties.

Sometimes, suppliers might not have enough ability to respond to the requirements of the buying organizations adequately. Their inabilities may be in various aspects, including environmental aspects and lack of willingness to collaborate with buying organizations [95]. This limits the applicability of supplier development practices and other green supply chain management practices. Studies show that suppliers' inabilities hinder the applicability of supplier development practices in buying organizations. Despite the fact that most supplier development practices only focus on developing suppliers' future capabilities [90], these suppliers require readily available skills to deal with the changes that occur in their buyer-supplier relationships. It should be noted that supplier development practices relate to some buyer-supplier relationships [80]. In addition, supplier development programs need adequate technological and managerial capabilities and environmental sensitivity to be successful. However, this is not the case for most suppliers [21]. That is why most supplier development activities are mainly concerned with improving the capabilities of the suppliers [67]. So, the existing capabilities of suppliers may provide a means for suppliers to be further developed effectively.

Moreover, some aspects of supplier development practices include the coordination of supplier development investments that entail collaborative relationships between suppliers and buyers. However, both parties may be reluctant to invest some resources in their relationship in some cases unless they are sure that investments will provide some profits for them [7]. This also poses a challenge for the effective implementation of supplier development practices. Generally, suppliers' willingness is necessary for suppliers to participate in public procurement opportunities [81]. Similarly, the willingness of suppliers is essential in supplier development practices [67]. Also, supplier willingness is crucial in ensuring that the relationship with the buyer is maintained and developed [66]. Therefore, suppliers' lack of willingness and reluctance toward supplier development hinder the success stories of supplier development in buyer-supplier relationships. This may also pose a challenge to the effective implementation of supplier development practices.

\section{Conclusions}

This article synthesizes the literature on several aspects of supplier development that may provide room for professional buyers to follow in the context of public procurement. Therefore, the article contributes to supplier management practices and public procurement literature by analyzing supplier development practices applicable in public procuring organizations. In particular, various supplier development practices are predominantly indirect practices relevant to public procurement. The article presents the rationale of supplier development practices and provides challenges that public procurement professionals should expect when deciding to engage in supplier development practices. However, the literature shows that despite the challenges affecting supplier development practices, there are factors that may be 
observed to ensure the success of supplier development practices. These factors may include the capabilities of the suppliers of suppliers, capabilities of the engaged suppliers, information sharing, and effective joint communication between suppliers and the buying organization [14].

The application of this article depends on the context of the research that the study is assumed to work. Most indirect supplier development practices apply in developing countries, like in most East African countries (including Tanzania), that operate in a relatively similar procurement legal environment. The country has six types of procuring entities in the public sector. These entities include government ministries, parastatal organizations, local government authorities, independent departments, agencies/authorities, and regional administrative secretaries. They procure works, goods, and services from a range of suppliers and contractors available across various areas of the country. Given the magnitude of government expenditure in public procurement activities, the need for developing suppliers will enhance proper management of allocated funds by reducing costs incurred on the poor quality of supplies, deliveries, and unexpected longer lead times.

The article establishes that procurement professionals in public organizations may indirectly apply some of the direct supplier development practices. However, by so doing, these practitioners must ensure that the challenges of managing suppliers through supplier development practices are controlled. Effective procurement contract management can help these buyers ensure that engaged suppliers are well managed. Through proper management of procurement contracts, public buyers can control the delivery time, procurement costs, and quality of procured goods and services [49]. Similar outcomes are experienced for manufacturers who are in relationships with suppliers of raw materials [68]. Adequacy and availability of materials may save manufacturers in the short run who operate in raw material markets characterized by supply rigidities [75]. In buyer-supplier relationships, contracts are employed as a safeguarding mechanism to protect the interests of both parties. Sometimes, these relationships are characterized by supplier development programs [34], and contracts are often used in supplier development programs [24, 58]. However, buyers should be cautious about the duration of the contract with the potential suppliers.

For instance, a study conducted by [91] focuses on analyzing the impact of contact extension on the mitigation of contractual hazards in relation to supplier development. Their study reveals that dynamically extended contracts boost the supplier development process by facilitating value creation while also giving flexibility to both manufacturers and suppliers. Furthermore, [24] studied the organizations that implement supplier development programs in the UK. Consequently, most organizations that were studied employed five-year contracts, with some only using one-year contracts. Because most indirect supplier development practices are conducted in the context of public procurement [50], buyers may have contracts with potential suppliers ranging from one to five years for supplier development programs to improve supplier performance.

Therefore, this article contributes to the debate of supplier development practices mainly relying on the private sector and mainly in manufacturing organizations by adding a reference to the public procurement context. Also, generalization of the application of supplier development practices in public procurement contexts should be made with precaution by considering the existing public procurement structure and regulatory framework of the specific country. Finally, the article recommends further empirical studies on dimensions of supplier development practices in public projects under which suppliers may only be developed in achieving objectives for specific construction projects in developing countries. This is because a lot of funds vested in public procurement are pretty significant in the procurement of works in terms of construction projects.

\section{Abbreviations}

OECD: Organisation for Economic Co-operation and Development; PPRA: Public Procurement Regulatory Authority; PSPTB: Procurement and Supplies Professionals and Technicians Board.

\section{Acknowledgements}

We would like to praise Almighty Allah for the blessing and support for conducting this study. Furthermore, I (corresponding author) express my heartfelt gratitude to my supervisors, who are co-authors of this manuscript, for their support and encouragement during the PhD journey. The authors would like to thank the anonymous reviewers for their constructive comments and suggestions that resulted in this work. Finally, we thank the Specialized Presidential Council for Education and Scientific Research (Government of Egypt) for covering the publication costs for articles in Future Business Journal that enable us not to have to pay an article-processing charge for this manuscript.

\section{Authors' contributions}

IAC developed the idea and carried out this study as a first author under the supervision of Dr. IJI and Dr. ADM. All authors read and approved the final manuscript.

\section{Funding}

This manuscript is the outcome of the Doctor of Philosophy (PhD) program, which the corresponding author pursues at the University of Dodoma. The University of Dodoma (the employer of the corresponding author) fully funds the program under an internal scholarship named "internal funds for longterm scholarship programs."

Availability of data and materials Not applicable. 


\section{Declarations}

\section{Competing interests}

The authors declare that they have no competing interests.

\section{Author details}

${ }^{1}$ Department of Business Administration and Management, The University of Dodoma, P.O. Box 1208, Dodoma, Tanzania. '2Department of Marketing, Procurement, and Supply Management, Moshi Co-operative University, P.O. Box 474, Moshi, Tanzania.

\section{Received: 12 August 2021 Accepted: 30 October 2021}

Published: 17 November 2021

\section{References}

1. Ağan Y, Acar MF, Neureuther B (2018) The importance of supplier development for sustainability. In: Zeimpekis V, Aktas E, Bourlakis M, Minis I (eds) Sustainable freight transport. Operations research/computer science interfaces series, 1st edn. Springer, Cham, pp 165-178

2. Agrifoglio R, Metallo C, di Nauta P (2021) Understanding knowledge management in public organizations through the organizational knowing perspective: a systematic literature review and bibliometric analysis. Public Organ Rev 21:137-156. https://doi.org/10.1007/s11115-020-00480-7

3. Andersen $\mathrm{PH}$, Ellegaard C, Kragh H (2020) How purchasing departments facilitate organizational ambidexterity. Prod Plan Control. https://doi.org/ 10.1080/09537287.2020.1818326

4. Arráiz l, Henríquez F, Stucchi R (2013) Supplier development programs and firm performance: evidence from Chile. Small Bus Econ 41:277-293. https://doi.org/10.1007/s11187-012-9428-x

5. Arroyo-López P, Holmen E, de Boer L (2012) How do supplier development programs affect suppliers? Insights for suppliers, buyers and governments from an empirical study in Mexico. Bus Process Manag J 18:680-707. https://doi.org/10.1108/14637151211253792

6. Bai C, Sarkis J (2010) Green supplier development: analytical evaluation using rough set theory. J Clean Prod 18:1200-1210. https://doi.org/10. 1016/j.jclepro.2010.01.016

7. Bai C, Sarkis J (2016) Supplier development investment strategies: a game theoretic evaluation. Ann Oper Res 240:583-615. https://doi.org/10.1007/ s10479-014-1737-9

8. Bai C, Satir A (2020) Barriers for green supplier development programs in manufacturing industry. Resour Conserv Recycl. https://doi.org/10.1016/j. resconrec.2020.104756

9. Balboni B, Marchi G, Vignola M (2017) Knowledge transfer in the context of buyer-supplier relationship: an analysis of a supplier's customer portfolio. J Bus Res 80:277-287. https://doi.org/10.1016/j.jbusres.2017.06.022

10. Bengtsson M (2016) How to plan and perform a qualitative study using content analysis. Nursing Plus Open 2:8-14. https://doi.org/10.1016/j. npls.2016.01.001

11. Benton WC, Prahinski C, Fan Y (2020) The influence of supplier development programs on supplier performance. Int J Prod Econ 230:107793. https://doi.org/10.1016/j.ijpe.2020.107793

12. Blome C, Hollos D, Paulraj A (2014) Green procurement and green supplier development: antecedents and effects on supplier performance. Int J Prod Res 52:32-49. https://doi.org/10.1080/00207543.2013.825748

13. Burt DN, Dobler DW, Starling SL (2003) World class supply management: the key to supply chain management, 7th ed. McGraw-Hill/Irwin, Boston

14. Busse C, Schleper MC, Niu M, Wagner SM (2016) Supplier development for sustainability: contextual barriers in global supply chains. Int J Phys Distrib Logist Manag 46:442-468. https://doi.org/10.1108/ IJPDLM-12-2015-0300

15. Changalima IA, Mushi GO, Mwaiseje SS (2021) Procurement planning as a strategic tool for public procurement effectiveness: experience from selected public procuring entities in Dodoma city, Tanzania. J Public Procure 21:37-52. https://doi.org/10.1108/JOPP-05-2020-0047

16. Chen L, Ellis S, Holsapple C (2015) Supplier development: a knowledge management perspective. Knowl Process Manag 22:250-269

17. Chidambaranathan S, Muralidharan C, Deshmukh SG (2009) Analyz ing the interaction of critical factors of supplier development using interpretive structural modelling —an empirical study. Int J Adv Manuf Technol 43:1081-1093. https://doi.org/10.1007/s00170-008-1788-7

18. Dalvi MV, Kant R (2018) Effect of supplier development activities on performance outcomes: an empirical study. Benchmarking 25:489-516. https://doi.org/10.1108/BIJ-07-2016-0107

19. Dastyar H, Pannek J (2019) Numeric evaluation of game-theoretic collaboration modes in supplier development. Appl Sci 9:1-15. https://doi. org/10.3390/app9204331

20. Dastyar H, Rippel D, Freitag M (2020) Optimization of supplier development under market dynamics. Math Probl Eng 2020:1-18. https://doi.org/ 10.1155/2020/2912380

21. Ehrgott M, Reimann F, Kaufmann L, Carter CR (2013) Environmental development of emerging economy suppliers: antecedents and outcomes. J Bus Logist 34:131-147. https://doi.org/10.1111/jbl.12015

22. Etse D, McMurray A, Muenjohn N (2021) Comparing sustainable public procurement in the education and health sectors. J Clean Prod 279:123959. https://doi.org/10.1016/j.jclepro.2020.123959

23. Fiaz S, Qureshi MA (2021) How perceived organizational politics cause work-to-family conflict? Scoping and systematic review of literature. Futur Bus J 7:1-18. https://doi.org/10.1186/s43093-020-00046-5

24. Galt JDA, Dale BG (1991) Supplier development: a British case study. Int J Purch Mater Manag 27:16-22. https://doi.org/10.1111/j.1745-493x.1991 tb00524.x

25. Glavee-Geo R (2019) Does supplier development lead to supplier satisfaction and relationship continuation? J Purch Supply Manag 25:100537. https://doi.org/10.1016/j.pursup.2019.05.002

26. Govindan K, Aditi DD, J, Kaul A, Jha PC, (2021) Structural model for analysis of key performance indicators for sustainable manufacturer-supplier collaboration: a grey-decision-making trial and evaluation laboratorybased approach. Bus Strateg Environ 30:1702-1722. https://doi.org/10. 1002/bse.2703

27. Guarnieri P, Gomes RC (2019) Can public procurement be strategic? A future agenda proposition. J Public Procure 19:295-321. https://doi.org/ 10.1108/JOPP-09-2018-0032

28. Hahn CK, Watts CA, Kim KY (1990) The supplier development program: a conceptual model. J Purch Mater Manag 26:2-7. https://doi.org/10. 1111/j.1745-493x.1990.tb00498.x

29. Hawkins TG, Muir WA (2014) An exploration of knowledge-based factors affecting procurement compliance. J Public Procure 14:1-32. https://doi. org/10.1108/JOPP-14-01-2014-B001

30. Humphreys P, Cadden T, Li WL, McHugh M (2011) An investigation into supplier development activities and their influence on performance in the Chinese electronics industry. Prod Plan Control 22:137-156. https:// doi.org/10.1080/09537281003733762

31. Jääskeläinen A (2021) The relational outcomes of performance management in buyer-supplier relationships. Int J Prod Econ 232:107933. https:// doi.org/10.1016/j.ijpe.2020.107933

32. Jin Y, Hu Q, Kim SW, Zhou SX (2019) Supplier development and integration in competitive supply chains. Prod Oper Manag 28:1256-1271. https://doi.org/10.1111/poms.12984

33. Joshi S, Kharat M, Raut R, Kamble S, Kamble S (2017) To examine the relationships between supplier development practices and supplier-buyer relationship practices from the supplier's perspective. Benchmark An Int 24:1309-1336. https://doi.org/10.1108/BIJ-01-2016-0006

34. Joshi SP, Shitole P, Chavan R, Joshi PP (2018) Strategies for buyer supplier relationship improvement: scale development and validation. In: Procedia manufacturing, pp 470-476

35. Kenosi N, van der Lingen E (2021) Corporate's enterprise and supplier development (ESD) for SMMEs through incubation programme. In: Entrepreneurship, technology commercialisation, and innovation policy in Africa. Springer, Cham

36. Knack S, Biletska N, Kacker K (2019) Deterring kickbacks and encouraging entry in public procurement markets: evidence from firm surveys in 90 developing countries. World Bank Econ Rev 33:287-309. https://doi.org/ 10.1093/wber/lhy016

37. Krause DR (1999) The antecedents of buying firms' efforts to improve suppliers. J Oper Manag 17:205-224. https://doi.org/10.1016/S0272-6963(98) 00038-2

38. Krause DR, Ellram LM (1997) Success factors in supplier development Int J Phys Distrib Logist Manag 27:39-52. https://doi.org/10.1108/09600 039710162277 
39. Krause DR, Ellram LM (1997) Critical elements of supplier development: the buying-firm perspective. Eur J Purch Supply Manag 3:21-31. https://doi.org/10.1016/S0969-7012(96)00003-2

40. Krause DR, Handfield RB, Scannell TV (1998) An empirical investigation of supplier development: reactive and strategic processes. J Oper Manag 17:39-58. https://doi.org/10.1016/50272-6963(98)00030-8

41. Lawson B, Krause D, Potter A (2015) Improving supplier new product development performance: the role of supplier development. J Prod Innov Manag 32:777-792. https://doi.org/10.1111/jpim.12231

42. Leenders MR (1966) Supplier development. J Purch 2:47-62

43. Li S, Kang M, Haney MH (2017) The effect of supplier development on outsourcing performance: the mediating roles of opportunism and flexibility. Prod Plan Control 28:599-609. https://doi.org/10.1080/09537 287.2017.1309711

44. Liu L, Zhang M, Hendry LC, Bu M, Wang S (2018) Supplier development practices for sustainability: a multi-stakeholder perspective. Bus Strateg Environ 27:100-116. https://doi.org/10.1002/bse.1987

45. Liu Y, Li Y, Shi LH, Liu T (2017) Knowledge transfer in buyer-supplier relationships: the role of transactional and relational governance mechanisms. J Bus Res 78:285-293. https://doi.org/10.1016/j.jbusres. 2016.12.024

46. Lo SM, Zhang S, Wang Z, Zhao X (2018) The impact of relationship quality and supplier development on green supply chain integration: a mediation and moderation analysis. J Clean Prod 202:524-535. https:// doi.org/10.1016/j.jclepro.2018.08.175

47. Luzzini D, Ronchi S (2011) Organizing the purchasing department for innovation. Oper Manag Res 4:14-27. https://doi.org/10.1007/ s12063-010-0042-2

48. Matto MC, Ame AM, Nsimbila PM (2021) Tender process and value for money in Tanzania public procurement. Int J Logist Econ Glob 9:1-23. https://doi.org/10.1504/IJLEG.2021.116218

49. Matto MC, Ame AM, Nsimbila PM (2021) Influence of contract management on value for money procurement in Tanzania. Int J Procure Manag 14:724-741. https://doi.org/10.1504/JPM.2020.10034350

50. McKevitt DM, Davis P (2014) Supplier development and public procurement: allies, coaches and bedfellows. Int J Public Sect Manag 27:550-563. https://doi.org/10.1108/IJPSM-03-2014-0041

51. McKevitt DM, Davis P (2015) How to interact, when and with whom? SMEs and public procurement. Public Money Manag 35:79-86. https:// doi.org/10.1080/09540962.2015.986897

52. Melander L, Arvidsson AP (2020) Getting innovations out of interactions in the public procurement context. J Bus Ind Mark 35:2051-2065. https://doi.org/10.1108/JBIM-09-2019-0414

53. Modi SB, Mabert VA (2007) Supplier development: improving supplier performance through knowledge transfer. J Oper Manag 25:42-64. https://doi.org/10.1016/j.jom.2006.02.001

54. Mohanty MK, Gahan P, Choudhury S (2014) Why most of the supplier development programs fail in discrete manufacturing-findings from selected Indian discrete manufacturing industries. Int J Manag Sci Eng Manag 9:201-211. https://doi.org/10.1080/17509653.2014.884454

55. Monczka RM, Trent RJ, Callahan TJ (1993) Supply base strategies to maximize supplier performance. Int J Phys Distrib Logist Manag 23:42-54. https://doi.org/10.1108/09600039310041509

56. Montalbán-Domingo L, García-Segura T, Sanz MA, Pellicer E (2018) Social sustainability criteria in public-work procurement: an international perspective. J Clean Prod 198:1355-1371. https://doi.org/10. 1016/j.jclepro.2018.07.083

57. Moroni-Cutovoi IT (2021) An examination of competitive strategy in buyer-supplier relationships for remanufacturing. J Remanuf 6:66

58. Mukucha P, Chari F (2021) The influence of supplier development, in the form of contract farming, on performance in Zimbabwean tobacco industry. Cogent Bus Manag. https://doi.org/10.1080/23311975.2021. 1968732

59. Nowell LS, Norris JM, White DE, Moules NJ (2017) Thematic analysis: striving to meet the trustworthiness criteria. Int J Qual Methods 16:1-13. https://doi.org/10.1177/1609406917733847

60. Organisation for Economic Co-operation and Development (OECD) (2015) Government at a Glance 2015. OECD Publishing, Paris

61. Organisation for Economic Co-operation and Development (OECD) (2019) Government at a Glance 2019. OECD Publishing, Paris
62. Osei-Kojo A, Bawole JN, Sakyi EK (2020) The opportunities and constraints to collaboration in public sector management. Public Organ Rev 20:495-510. https://doi.org/10.1007/s11115-019-00452-6

63. Pellegrino R, Costantino N, Tauro D (2020) The role of risk management in buyer-supplier relationships with a preferred customer status for total quality management. TQM J 32:959-981. https://doi.org/10.1108/ TQM-04-2019-0107

64. Pihlajamaa M, Kaipia R, Aminoff A, Tanskanen K (2019) How to stimulate supplier innovation? Insights from a multiple case study. J Purch Supply Manag 25:100536. https://doi.org/10.1016/j.pursup.2019.05.001

65. Pollock A, Berge E (2018) How to do a systematic review. Int J Stroke 13:138-156. https://doi.org/10.1177/1747493017743796

66. Rezaei J, Ortt R (2012) A multi-variable approach to supplier segmentation. Int J Prod Res 50:4593-4611. https://doi.org/10.1080/00207543. 2011.615352

67. Rezaei J, Wang J, Tavasszy L (2015) Linking supplier development to supplier segmentation using Best Worst Method. Expert Syst Appl 42:9152-9164. https://doi.org/10.1016/j.eswa.2015.07.073

68. Rounaghi MM, Jarrar H, Dana L (2021) Implementation of strategic cost management in manufacturing companies: overcoming costs stickiness and increasing corporate sustainability. Futur Bus J 7:1-8. https://doi.org/ 10.1186/s43093-021-00079-4

69. Saghiri SS, Mirzabeiki V (2021) Buyer-led environmental supplier development: Can suppliers really help it? Int J Prod Econ 233:107969. https://doi. org/10.1016/j.jpe.2020.107969

70. Sako M (2004) Supplier development at Honda, Nissan and Toyota: comparative case studies of organizational capability enhancement. Ind Corp Chang 13:281-308. https://doi.org/10.1093/icc/13.2.281

71. Salimian H, Rashidirad M, Soltani E (2021) Supplier quality management and performance: the effect of supply chain oriented culture. Prod Plan Control 32:942-958. https://doi.org/10.1080/09537287.2020.1777478

72. Sancha C, Gimenez C, Sierra V, Kazeminia A (2015) Does implementing social supplier development practices pay off? Supply Chain Manag 20:389-403. https://doi.org/10.1108/SCM-07-2014-0239

73. Sancha C, Longoni A, Giménez C (2015) Sustainable supplier development practices: drivers and enablers in a global context. J Purch Supply Manag 21:95-102. https://doi.org/10.1016/j.pursup.2014.12.004

74. Sánchez-Rodríquez C, Hemsworth D, Martínez-Lorente ÁR (2005) The effect of supplier development initiatives on purchasing performance: a structural model. Supply Chain Manag 10:289-301. https://doi.org/10. 1108/13598540510612767

75. Sankaran A, Krishna A, Vadivel A (2021) How does manufacturing output affect export behaviors in emerging market economies? Evidence from a dynamic panel ARDL for ten biggest emerging market economies. Futur Bus J 7:1-10. https://doi.org/10.1186/s43093-021-00072-x

76. Siddaway AP, Wood AM, Hedges LV (2019) How to do a systematic review: a best practice guide for conducting and reporting narrative reviews, meta-analyses, and meta-syntheses. Annu Rev Psychol 70:747-770. https://doi.org/10.1146/annurev-psych-010418-102803

77. Sikombe S, Phiri MA (2019) Exploring tacit knowledge transfer and innovation capabilities within the buyer-supplier collaboration: a literature review. Cogent Bus Manag 6:1-22. https://doi.org/10.1080/23311975. 2019.1683130

78. Sikombe S, Phiri MA (2021) How do institutionalized supplier development initiatives affect knowledge transfer and operational performance? Evidence from SME construction companies in Zambia. Afr J Sci Technol Innov Dev 6:66. https://doi.org/10.1080/20421338.2021.1889757

79. Sikombe S, Phiri MA (2021) Institutional factors influencing institutionalised supplier development initiatives in the construction industry in Zambia. Cogent Bus Manag. https://doi.org/10.1080/23311975.2021. 1935184

80. Sillanpää I, Shahzad K, Sillanpää E (2015) Supplier development and buyer-supplier relationship strategies - a literature review. Int J Procure Manag 8:227-250

81. Siwandeti M, Sanga C, Mfanga A, Panga FP (2021) Vendors' willingness drivers for participation in public electronic procurement system, Ilala District, Tanzania. In: Sustainable education and development, pp 445-454

82. Sönnichsen SD, Clement J (2020) Review of green and sustainable public procurement: towards circular public procurement. J Clean Prod 245:118901. https://doi.org/10.1016/j.jclepro.2019.118901 
83. Talluri S, Narasimhan R, Chung W (2010) Manufacturer cooperation in supplier development under risk. Eur J Oper Res 207:165-173. https://doi. org/10.1016/j.ejor.2010.03.041

84. Thai KV (2001) Public procurement re-examined. Public Procure 1:9-50. https://doi.org/10.1108/jopp-01-01-2001-b001

85. Thakker SV, Rane SB (2018) Implementation of green supplier development process model in Indian automobile industry. Manag Environ Qual An Int J 29:938-960. https://doi.org/10.1108/MEQ-03-2018-0052

86. Thomas J, Harden A (2008) Methods for the thematic synthesis of qualitative research in systematic reviews. BMC Med Res Methodol 8:1-10. https://doi.org/10.1186/1471-2288-8-45

87. Wagner SM (2006) Supplier development practices: an exploratory study. Eur J Mark 40:554-571. https://doi.org/10.1108/0309056061065783

88. Wagner SM (2010) Indirect and direct supplier development: Performance implications of individual and combined effects. IEEE Trans Eng Manag 57:536-546. https://doi.org/10.1109/TEM.2009.2013839

89. Wagner SM, Krause DR (2009) Supplier development: communication approaches, activities and goals. Int J Prod Res 47:3161-3177. https://doi. org/10.1080/00207540701740074

90. Watts CA, Hahn CK (1993) Supplier development programs: an empirical analysis. Int J Purch Mater Manag 29:10-17. https://doi.org/10.1111/j. 1745-493X.1993.tb00002.x

91. Worthmann K, Proch M, Braun P, Schlüchtermann J, Pannek J (2016) Towards dynamic contract extension in supplier development. Logist Res 9:1-12. https://doi.org/10.1007/s12159-016-0141-z
92. Yang F, Zhang X (2017) The impact of sustainable supplier management practices on buyer-supplier performance: an empirical study in China. Rev Int Bus Strateg 27:112-132. https://doi.org/10.1108/ RIBS-08-2016-0043

93. Yawar SA, Kauppi K (2018) Understanding the adoption of socially responsible supplier development practices using institutional theory: dairy supply chains in India. J Purch Supply Manag 24:164-176. https:// doi.org/10.1016/j.pursup.2018.02.001

94. Yawar SA, Seuring S (2018) The role of supplier development in managing social and societal issues in supply chains. J Clean Prod 182:227-237. https://doi.org/10.1016/j.jclepro.2018.01.234

95. Zaabi AS, Al Dhaheri N, Diabat A (2013) Analysis of interaction between the barriers for the implementation of sustainable supply chain management. Int J Adv Manuf Technol 68:895-905. https://doi.org/10.1007/ s00170-013-4951-8

96. Zhang M, Pawar KS, Bhardwaj S (2017) Improving supply chain social responsibility through supplier development. Prod Plan Control 28:500-511. https://doi.org/10.1080/09537287.2017.1309717

\section{Publisher's Note}

Springer Nature remains neutral with regard to jurisdictional claims in published maps and institutional affiliations.

\section{Submit your manuscript to a SpringerOpen ${ }^{\circ}$ journal and benefit from:}

- Convenient online submission

- Rigorous peer review

- Open access: articles freely available online

- High visibility within the field

- Retaining the copyright to your article

Submit your next manuscript at $\boldsymbol{\nabla}$ springeropen.com 